\title{
“Truth Vs. Slack Inducing” Paradox: How Does Compensation Scheme Mitigate Social Pressure on Budgetary Slack?
}

\author{
ARYAN DANIL MIRZA BR* \\ Universitas Gadjah Mada Yogyakarta \\ MARIA PARAMASTRI HAYUNING ADI \\ Universitas Bina Nusantara Jakarta
}

\begin{abstract}
This research aims to examine the role of the compensation scheme in mitigating the negative impact of social pressure on the creation of budgetary slack. There is an unclear phenomenon, how can compensation methods with pressure (penalty) be better able to reduce budgetary slack compared to compensation methods without penalty? This research contributes by validating the role of truth inducing and slack inducing compensation schemes in order to mitigate the budgetary slack through the perspective of expectancy theory. Results from an experimental study among 56 undergraduate accounting students showed that obedience pressure tends to encourage individuals to create budgetary slack compared to while they experience pressure from their peers (H1). Another finding from this research is the tendency of individuals to create budgetary slack tends to be lower when they accept the slack inducing compensation mechanism than truth inducing (H2). These indicate that slack inducing compensation scheme is better used than truth inducing in mitigating the creation of budgetary slack. Different levels of risk faced by the individual, especially in the absence offines or sanctions if the budget target is not reached, have different impacts on the individual. Our research provides practical implication when individuals receive stressed; compensation schemes are less effective in minimizing the effect of social pressure on the creation of budgetary slack
\end{abstract}

Keywords: Budgetary Slack, Obedience Pressure, Peer Pressure, Compensation Scheme

\begin{abstract}
Abstrak - Penelitian ini bertujuan untuk menguji peran skema kompensasi dalam memitigasi dampak negatif tekanan sosial terhadap penciptaan budgetary slack. Terdapat fenomena yang masih belum jelas, bagaimana bisa metode kompensasi dengan tekanan/penalti (truth inducing) dapat lebih mampu mengurangi senjangan anggaran dibandingkan dengan metode kompensasi tanpa penalti (slack inducing)? Penelitian ini berkontribusi dengan memvalidasi peran skema kompensasi truth inducing dan slack inducing dalam meminimalisir terjadinya budgetary slack mengunakan perspektif teori ekspektasi. Hasil dari penelitian eksperimen menggunakan 56 mahasiswa S1 akuntansi menunjukkan bahwa obedience pressure cenderung mendorong individu untuk membuat budgetary slack dibandingkan ketika
\end{abstract}

\footnotetext{
*Corresponding author: admbr29@gmail.com
} 
menerima peer pressure (H1). Temuan lain dari penelitian ini adalah kecenderungan individu untuk melakukan budgetary slack cenderung lebih rendah ketika berada dalam skema kompensasi slack inducing dibandingkan truth inducing (H2). Hal ini menunjukkan bahwa skema kompensasi slack inducing terbukti lebih baik untuk digunakan dibandingkan dengan truth inducing dalam memitigasi terjadinya budgetary slack. Perbedaan tingkat risiko yang dirasakan oleh individu, khsususnya ketika terdapat denda atau sanksi tambahan jika target anggaran tidak tercapai, memberikan dampak yang berbeda terhadap individu. Penelitian kami memberikan implikasi praktis, ketika individu mendapat tekanan, skema kompensasi menjadi kurang efektif dalam meminimalisir pengaruh tekanan sosial terhadap penciptaan budgetary slack.

Kata Kunci: Senjangan Anggaran, Tekanan Kepatuhan, Tekanan Rekan Sebaya, Skema Kompensasi.

\section{Introduction}

Budgeting becomes a serious concern for management and shareholders because it sets organization planning and future action that should be a guideline to achieve their goals or make several policy changes if needed. When under pressure, such as during the financial crisis, management has difficulty achieving the budget target and, therefore, have incentives to manipulate budget upward to meet predetermined targets and then to increase their chances of receiving a bonus (Assenso-Okofo et al., 2020).

Nowadays, the budget also becomes a performance standard for an employee, so the achievable of the budget is a mandatory thing for the employee. One of the common fraud is done by an employee to achieve their budget easier is by creating budgetary slack. Budgetary slack is considered an unethical action (Hobson et al. 2011) because it sets performance targets lower than actual organizational capabilities (Douglas and Wier, 2000).

Social pressure encourages the occurrence of budgetary slack (DeZoort and Lord, 1997). Lord and DeZoort (2001) find that social pressure raises conformance, the desire of individuals to avoid the negative consequences of acting disloyally towards someone whose position of authority is higher or acting following the wishes of the group. Davis et al. (2006) find that financial managers are proven to create budgetary slack when receiving pressure from superior, even though the managers are aware that their actions 
are wrong and contrary to their duties. In addition to pressure from superiors, pressure from peer pressure also plays a role in influencing the creation of budgetary slack, even though it is not as strong as encouragement from superiors or higher authorities. Chong and Syarifuddin (2010) provide evidence that accountants who experience pressure from colleagues tend to make unethical decisions that harm the company.

Budgetary slack can also be influenced by compensation scheme that applies in organizations, especially when compensation scheme is applied based on the achievement of the budget plans that have been prepared (Kramer and Hartman, 2014). The compensation scheme will bridge the interests of the principal and agent (Chen et al., 2001). Pepper and Gore (2015) argue that the interests of principals and their agents are likely to be harmonized if the individual is motivated to do their best. Langevin and Mendoza (2012) emphasize that, if the compensation scheme is considered unfair, it can lead managers to behave in a way that is harmful to the organization. For example, it may lead managers to have unethical behaviors. The agency theory perspective emphasizes that individuals are rational beings and will always be selfish by maximizing their welfare (Evans III et al. 2001).

Compensation scheme introduced as a control system to minimize budgetary slack. Expectancy theory (Vroom, 1994) explains that subordinates will be motivated to being excellent if it is related to the number of rewards offered by superiors in accordance with their expectancy. Hobson et al. (2011) introduced truth inducing pay schemes and slack inducing pay schemes as an alternative compensation scheme for reducing budgetary slack.

Waller (1988) found that budgetary slack tends to be smaller when companies use truth inducing scheme. Similar results were also presented in Chow et al. (1988), which stated that truth inducing compensation scheme could effectively reduce budgetary slack based on past performance budgets. Steven (2002); Fisher et al. (2002); Efrilna (2018); Sampouw (2018) also supported this result that truth inducing compensation scheme more able to reduce the number of the budgetary slack that made by subordinates than the slack inducing compensation scheme. 
These results provide a question for further research, how can compensation methods with pressure (penalty) be better able to reduce budgetary slack compared to compensation methods without penalty? Young (1985) suggests that when individuals (subordinates) are in a condition of uncertainty, then individuals will try to avoid risk (risk-averse) compared to individuals who do not experience conditions of uncertainty. Young (1985) examined the effect of risk on the budgetary slack and provided evidence that subordinates who were risk-averse tended to make larger budgetary slack than nonrisk averse subordinates. In the context of truth inducing compensation scheme and slack inducing scheme, while faced with pressure fines or salary reductions, individuals who tend to risk-averse will avoid these fines and will eventually try to avoid these risks. When subordinates are unable to reach the budget target, the risk-averse subordinates tend to do budgetary slack to avoid the risk of salary reduction. On the other hand, in slack inducing compensation schemes, without reducing pressure, individuals do not experience conditions of uncertainty and pressure to reduce salaries, so they are predicted not to make budgetary slack.

This topic becomes very interesting to be examined, especially related to the pressure experienced by individuals on truth inducing. Indirectly, truth inducing compensation schemes can also be the compliance pressure, which also provides additional pressure for individuals. Contrary to truth inducing, the risk of getting this fine is not found in slack inducing, so it is believed to minimize the occurrence of budgetary slack than truth inducing. Because, if the budget target fails to be achieved, the slack inducing compensation scheme will only abolish the provision of bonuses without reducing the basic salary.

Using 56 accounting students in experimental research, this research wants to examine how compensation scheme (truth inducing and slack inducing) can mitigate social pressure effects on budgetary slack creation. This research also investigates which social pressure (obedience pressure or peer pressure) and compensation scheme (truth inducing or slack inducing) have more influence in reducing budgetary slack creation. This research adopts a social pressure case scenario by Hartman and Mass 
(2010) and tries to measure the different effects of social pressure from superiors and peers that have not been measured in other research before.

This research also tried to validate previous studies such as Waller (1988); Chow et al. (1988); Steven (2002); Fisher et al. (2002); Efrilna (2018); Sampouw (2018) who believed that the truth inducing compensation scheme was able to reduce the size of the budgetary slack made by subordinates than slack inducing compensation scheme. In addition, this research wants to examine different perspectives regarding the possibility of a slack inducing compensation scheme that can reduce budgetary slack based on Young's argument (1985).

\section{Theoretical Framework and Hypothesis Development}

Since the budget always used as a performance measurement tool, budgetary slack usually becomes an important issue in the organization. Budgetary slack is the difference between the amount of budget submitted by subordinates and the best number of estimates that have been submitted and made at the time of budgeting (Anthony \& Govindarajan, 2007). Budgetary slack is created when subordinates downplay their abilities or the ability of business units to be included in the budget target (Hobson et al. 2011). Subordinates will downplay their productive abilities to ensure the achievement of standards set in the target (Young, 1985). Budgetary slack can be created by overestimating cost estimates, minimizing revenue estimates, and reducing production capacity. Management accountants do budgetary slack in this case so that the budget can be more easily achieved. Practices like this will certainly cause losses for the company in the future.

Many factors affect these unethical actions; one of them is the pressure from the supervisor or co-workers-workers. The relationship among peers unwittingly creates a social pressure that influences one another. Kelman (1958), through social influence theory, explains that individuals can change their behavior to adjust demand from their social environment, one of which is pressure from superiors and pressure from peers. Individuals can change their selves to meets the demands of a social environment. It takes many forms and can be seen in conformity, socialization, obedience pressure, peer 
pressure, and persuasion (Kelman, 1958).

Milgram (1965) states that subordinates will act not on their own desires but because they have to fulfill the desires of figures who are considered to have high authority. Individuals subjected to obedience pressure will make a decision contrary to their attitudes, beliefs, and values because they can remove themselves from responsibility for their judgments and decisions after an individual with authority directs them to action (Milgram, 1965; 1974). Meanwhile, peer pressure as an alternative form of social influence pressure refers to behavior affected by equals or peers. Peer pressure comes with the situation when people conform in normative influence situations because they fear negative consequences if they appear deviant from others (Bhrem and Kassin, 1990; Deutsch and Gerrard, 1955; Lord and De Zoort, 2001). Therefore, social pressure, such as obedience pressure and peer pressure, will encourage budgetary slack creation because the employee feels pressure and afraid to their supervisor or figures who have high authority and their team (peer).

Compensation scheme introduced as a control system to minimize budgetary slack. Expectancy theory (Vroom, 1994) explains that subordinates will be motivated to being excellent if it is related to the number of rewards offered by superiors in accordance with their expectancy. Hobson et al. (2011) introduced truth inducing pay scheme and slack inducing pay scheme as an alternative compensation scheme. Truth inducing compensation scheme is compensation with a reward if the employee can achieve their target and penalty if they did not achieve, meanwhile slack inducing compensation scheme is compensation with reward but without penalty. Compensation scheme as management control systems is an important tool to minimize budgetary slack that arose from social pressure.

\subsection{Obedience Pressure Vs. Peer Pressure on Budgetary Slack}

Social pressure has been used to predict individual behavior in making formal decisions. Battison and Gamba (2016) show that social pressure can be a positive pressure, resulting in beneficial and beneficial decisions. On the other hand, social 
pressure can also be a negative pressure or improper order that result in adverse decisions. Obedience Pressure (Milgram, 1965; Davis et al. 2006) is social pressure originated from individuals who have a bigger influence and authority, such as supervisor or manager.

Milgram (1965) states that subordinates will act not on their own desires but because they have to fulfill the desires of figures who are considered to have high authority. Davis et al. (2006) found that almost half of the financial managers who were participants in the experiment proved to have budgetary slack when getting pressure from superiors. Although actually, the managers are aware that the actions they take are wrong and contrary to their duties. The individual will be willing to behave in a way that is deviant from his position, beliefs, and values because other individuals with higher authority have controlled him.

Meanwhile, peer pressure (Lord and DeZort, 2001; Chong and Syarifuddin, 2010) is a social pressure that comes from colleagues. Lord and DeZoort (2001) research found that social pressures lead to conformance, the desire of individuals to avoid the negative consequences of acting disloyal towards someone whose position of authority is higher or not following the wishes of the group. Peer pressure is not usually as strong as the obedience pressure in influencing someone because of the absence of a range of forces in this type of pressure (Lord and DeZort, 2001). Nevertheless, the theory of social influence in accounting research states that pressure can influence the auditor's judgment in facing an ethical dilemma. Research by Chong and Syarifuddin (2010) shows evidence that accountants who experience pressure from peers tend to make unethical decisions that harm the company.

Huddart and Qu (2014) found that the manager's honesty would diminish when he found other peer managers acting dishonestly. On the other hand, the manager's honesty will increase when he finds the behavior of other manager peers to be honest in reporting. Cannon and Thornock (2018) also show that peer pressure can also have a large influence on decisions taken by managers in the budgeting process. This happens because managers feel part of a group with a peer, especially when dealing with the 
same situation. So, the manager's actions will adjust to the action of another peer manager (Turner et al., 1987).

There is limited research that measures and compares the differential impact of social pressure on individual behavior in the budgeting process (research on social pressure usually only uses one type of social pressure or uses a combination of social pressure). So, this research tries to compare the different effects of social pressure on budgetary slack creation. Based on these arguments, we formulated the hypothesis as follows:

H1: Budgetary slack tends to be higher when individuals receive obedience pressure than peer pressure.

\subsection{Truth Inducing Vs. Slack Inducing on Budgetary Slack}

Budgetary slack can also be influenced by compensation scheme that applies in organizations, especially when compensation scheme is applied based on the achievement of the budget plans that have been prepared (Kramer and Hartman, 2014). Although, Fahlenbrach and Stulz (2011) find that bank CEOs whose incentives are aligned with the interests of shareholders do not perform any better than those whose incentives are not aligned, Bhuyan, et al. (2020) who examined compensation schemes in the insurance industry found that compensation schemes are closely related to the company's financial performance in the future.

The agency theory perspective suggests that individuals are rational beings and will always be selfish by maximizing their personal welfare (Evans III et al. 2001). Reward offered by leaders will affect the performance of subordinates. According to expectancy theory (Vroom, 1994), subordinates will be motivated to excel if it is related to the number of rewards offered by superiors in accordance with their expectancy. However, in reality, the amount of compensation received is not always as expected. When the method of reward or compensation offered to subordinates is not informed, it will result in a decrease in performance. In one way, compensation settings that do not help in solving agency problems but perhaps exacerbate them (Van Essen et al., 2015). 
Likewise, if subordinates do not present the actual potential of the budget, it can result in the emergence of budgetary slack.

Compensation paid either to superiors or subordinates can motivate the occurrence of a moral hazard if the calculation or compensation method is not in accordance with what is expected either by superiors or subordinates (Chow et al., 1988). For superiors and subordinates: the more risks are borne, the higher the expected compensation. Carreras and Naranjo-Gril's (2014) found empirical evidence that bonus incentives cause individuals to justify any means to get bonuses, including creating budgetary slack.

The Truth Inducing Pay scheme (Hobson et al., 2011) is a compensation payment scheme where subordinates will receive maximum compensation if the actual output is the same as the budgeted or proposed production plan. If the actual result is smaller than the proposal, so the subordinates will be fined or penalized. Hobson et al. (2011) provide an example of a formula for calculating truth inducing payment scheme:

$$
\begin{array}{ll}
P=\$ 0.10 B+\$ 0.05(A-B), & \text { if } A \geq B, \\
P=\$ 0.10 B-\$ 0.15(A-B), & \text { if } A<B .
\end{array}
$$

Meanwhile, slack inducing the Pay Scheme or fixed pay plus Bonus is a compensation method where subordinates are paid by a fixed salary plus a bonus if the output exceeds the target and without penalty. If the production is less than the target, they will receive compensation in the form of a fixed salary only. Hobson et al. (2011) also provide an example of a formula for calculating slack inducing payment scheme:

$$
\begin{array}{ll}
P=\$ 0.10 B+\$ 0.05(A-B), & \text { if } A \geq B, \\
P=\$ 0.10 B, & \text { if } A<B .
\end{array}
$$

Waller (1988) found that the budgetary slack occurs to be smaller when companies use truth inducing methods. Similar results were also presented in Chow et al. (1988), which stated that truth inducing compensation scheme could effectively reduce budgetary slack based on past performance budgets. Steven (2002) and Fisher et al. (2002) also supported this result that truth inducing compensation scheme more able to 
reduce the size of the budgetary slack that made by subordinates than the slack inducing compensation scheme.

Research on compensation schemes in Indonesia also shows the same direction, where the slack inducing compensation scheme will create larger budgetary slack than truth inducing compensation scheme (Efrilna, 2018; Sampouw, 2018). Truth inducing scheme has a mechanism that can make higher budgetary slack, where additional reward or sanctions for the achievement of the target or not reached will motivate the subject to propose a budget with real abilities and then make the subject motivated to achieve the budgeted target (Palupi and Mulyatno, 2014).

There is another perspective on this compensation scheme. Contrary with all researcher who argues that truth is inducing able to reduce budgetary slack, Young (1985) gives another perspective. Young (1985) suggests that when individuals (subordinates) are in a condition of uncertainty, then individuals will try to avoid risk (risk-averse) compared to individuals who do not experience conditions of uncertainty. Young (1985) examined the effect of risk on the budgetary slack and provided evidence that subordinates who were risk-averse tended to make larger budgetary slack than nonrisk averse subordinates. In the context of truth inducing compensation scheme and slack inducing scheme, while faced with pressure penalty or salary reductions, individuals who tend to risk-averse will avoid these fines and will eventually try to avoid these risks. When subordinates are unable to reach the budget target, the risk-averse subordinates tend to do budgetary slack to avoid the risk of salary reduction.

On the slack inducing, the risk of getting this penalty is not found, so it is believed can minimize the occurrence of budgetary slack than truth inducing. Because of the budget target fails to be achieved, the slack inducing compensation scheme will only abolish the provision of bonuses without reducing the basic salary. Therefore, the bottom manager (manage ment accountant) of budget compilers will tend to create slack on the proposed budget in truth inducing scheme. This is because in addition to the bottom manager (management accountant) the budget compiler is motivated to get a 
bonus; it is also more influenced because it avoids the risk of getting a fine if the actual performance results fail to reach the proposed budget target.

In general, participatory budgeting is at risk of encouraging employees to carry out budgetary slack. However, the different compensation schemes used to provide a different level of a tendency to do budgetary slack. Based on this explanation, we formulated the hypothesis as follows:

H2: Budget slack tends to be lower in slack inducing compensation schemes than truth inducing

\subsection{Effects of Social Pressure and Compensation Scheme on Budgetary Slack}

One way to make budgeting easier is to create budgetary slack, which Webb (2002) translates as a performance target that is deliberately made more than the expected level. Davis et al. (2006) evaluated the vulnerability to obedience pressure for management accountants to create budgetary slack in violation of company policy. This indicated that participants who added slack to the initial budget recommendations found their own lack of responsibility for a budget decision that had been made compared to participants who refused to add slack.

Emett et al. (2019) found evidence that individuals adjust to the actions of selfish peers that lead to a gradual movement towards non-compliance with management's expectations or regulatory requirements in an accounting context. Individuals are vulnerable to peer influence because they join with a peer in making the report (Brunner and Ostermaier, 2019). This happens because social pressure leads to conformance, the desire of individuals to avoid the negative consequences of acting disloyally towards someone whose position of authority is higher or not following the wishes of the group (Lord and DeZoort, 2001)

The compensation scheme that applies to the company plays a vital role in the creation of budgetary slack. Social pressure will be stronger when the compensation scheme used has a large influence on compensation to be obtained by all members of the company. So, every budget decision that will be taken can have a broad impact on all individuals in the company. The use of different compensation schemes is believed 
to have different social pressure effects.

Truth inducing compensation scheme is looked riskier for company employees than slack inducing compensation scheme. This happens because if the company's performance fails to reach the target, so truth inducing compensation will provide a penalty in the form of deducting the basic salary of management or company employees. On the other side, the slack inducing compensation scheme will only abolish Bonus giving without reducing basic salary (Waller, 1988; Chow et al., 1988) So, many researchers believe, including Fisher et al. (2002); Efrilna (2018); Sampouw (2018), that truth inducing compensation scheme more able to reduce the size of the budgetary slack that made by subordinates than the slack inducing compensation scheme.

Young's (1985) examined the effect of risk on the budgetary slack and found the result, if subordinates are in a condition of uncertainty, then the risk-averse subordinates tend to make a larger budgetary slack than non-risk averse subordinates. While the slack inducing risk of getting this fine (penalty) is not found, so it is believed to minimize the occurrence of budgetary slack than truth inducing. Therefore, in truth inducing, managers under budget compilers will tend to create slack on the proposed budget because besides being motivated to get bonuses, they are also more influenced because they avoid the risk of obtaining fines if the actual performance results fail to reach the proposed budget target. Based on this explanation, we formulated the hypothesis as follows:

H3: The compensation scheme moderates the effect of social pressure on budgetary slack.

H3a: Budget slack tends to be lower in slack inducing compensation scheme than truth inducing when individuals receive obedience pressure.

H3b: Budgetary slack tends to be lower in slack inducing compensation schemes than truth inducing when individuals receive peer pressure

We describe the relationship between the variables in the following research model: 
Figure 1

Conceptual Model

\section{Social Pressure}

(Obedience Pressure

$\&$ Peer Pressure)

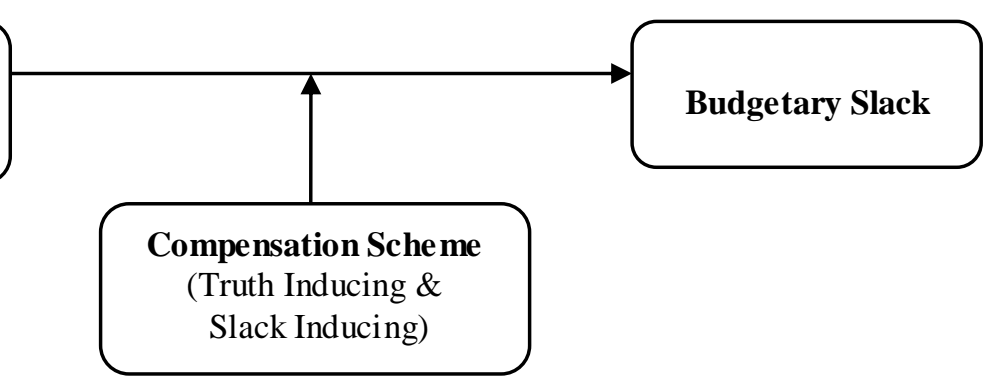

\section{Research Method}

\subsection{Research Design}

This research uses an experimental method to explain the causal relationship between social pressure and compensation schemes towards the creation of budgetary slack. This research used $2 \times 2$ factorial design between the subject with social pressure (obedience pressure and peer pressure) as an independent variable, compensation schemes (truth inducing and slack inducing) as moderating variable and budgetary slack as the dependent variable. Table 1 below shows the experimental design clearly.

Table 1

Experimental Design

\begin{tabular}{|c|c|c|c|}
\hline \multirow{2}{*}{ Factor dan Level } & \multicolumn{2}{c|}{ Compensation Scheme } \\
\cline { 3 - 4 } & Truth Inducing & Slack Inducing \\
\hline \multirow{2}{*}{ Social Pressure } & Obedience Pressure & 14 Participants & 14 participants \\
\cline { 2 - 4 } & Peer Pressure & 14 Participants & 14 Participants \\
\hline
\end{tabular}

\subsection{Research Participants}

The participants in this experiment were 62 accounting students who had taken the management accounting subject. So they were considered to have sufficient ability to understand and work on experimental cases regarding budgeting, one of the subjects of Management Accounting. The budgeting process includes budgetary slack has been explained well in Management Accounting subject. Therefore, students can able to internalize the situation and understand this issue. Khera and Benson (1970) explain that 
college students could be chosen as participants because students can act like a businessman when they understand and can internalizing experimental tasks clearly. This research uses a simple budgeting case instrument, so the use of accounting student participants is believed to be sufficiently capable of internalizing understanding of the case. This research uses participants from private universities in Lampung because the student rarely involved in experimental research. This condition is chosen to minimize the demand effect, the situation in which participants can act unnatural (Nahartyo and Utami, 2016).

\subsection{Experiment Procedure}

Before the experiment took place, participants were divided randomly from one of the four existing case scenario packages:

- Obedience Pressure - Truth Inducing

- Obedience Pressure - Slack Inducing

- Peer Pressure - Truth Inducing

- Peer Pressure - Slack Inducing

In the initial stage, participants will receive general information regarding the company and its role in P.T. Prima Jaya Otoparts. Participants will also get information about budget realization over the past three years for the 2019 budgeting process. In the next stage, participants will be explained the compensation scheme that applies to the company. To validate understanding regarding compensation schemes, participants are given the task of calculating how much compensation they will receive if the company's target is reached or fails to achieve.

On the next stage, participants will receive pressure from their superiors or peers to revise the budget targets to be more easily achieved. The dilemma in making this decision is the important point in this experiment. The final decision of the participants how much the budget is proposed. The researcher will see whether the participant's answer contains slack or not and then calculates the amount of slack produced. 


\section{Results and Discussion}

\subsection{Data and Demography}

The data that could be processed were 56 participants ( 15 male and 41 female) because six respondents failed to pass the manipulation check (9.6\%). The average age of participants is 21.09 years with a minimum age is 19 years, and the maximum age is 23 years. Some participants have work experience of around 1-3 years.

All participants get a random assignment to eliminate and reduce the bias due to differences in participant characteristics (Nahartyo and Utami, 2016). Randomization testing using Chi-Square showed a significance value of 0.801 ( $p>0.05)$ for the gender variable, $0.960(p>0.05)$ for the age variable, and 0.845 ( $p>0.05)$ for the work experience variable. The randomization test results showed that there were no differences between manipulation groups based on sex, age, and work experience ( $p>$ $0.05)$.

Table 2

Randomized Test Result

\begin{tabular}{|c|c|c|}
\hline \multirow{2}{*}{ Demography Characteristics } & \multicolumn{2}{|c|}{ Budgetary Slack } \\
\cline { 2 - 3 } & Pearson Chi-Square & Sign. \\
\hline Sex & 1.002 & 0.801 \\
\hline Age & 4.942 & 0.960 \\
\hline Work Experience & 4.876 & 0.845 \\
\hline
\end{tabular}

These demography factors were tested to ensure that participants' demography characteristics (gender, age, work experience) do not affect the dependent variable. This research using one-way ANOVA to test gender and linear regression to test age and work experience to the dependent variables. The test results show that there is no influence of demography characteristics, which are sex, age, and work experience on the dependent variable. One-way ANOVA test for sex variables on budgetary slack has a significance value of $0.114(\mathrm{p}>0.05)$. The linear regression test results for the age variable has value of $0.066(p>0.05)$ and work experience $0.341(p>0.05)$. Based on this result, there is no influence of participant demography characteristics on the budgetary slack variable. 
The Indonesian Journal of Accounting Research - May, Vol. 23, No.2, 2020

Table 3

Test Results the Effect of Demography Characteristics on Dependent Variable

\begin{tabular}{|c|c|c|}
\hline \multirow{2}{*}{ Demography Characteristics } & \multicolumn{2}{|c|}{ Budgetary Slack } \\
\cline { 2 - 3 } & F & Sign. \\
\hline Sex & 2.584 & 0.114 \\
\hline Age & 3.531 & 0.066 \\
\hline Work Experience & 0.924 & 0.341 \\
\hline
\end{tabular}

\subsection{Result}

The results of testing hypothesis 1 in table 2 show the significance of 0.047 ( $p<0.05)$, which means that hypothesis 1 is statistically supported. Individuals tend to do higher budgetary slack when receiving social pressure from superiors than social pressure from peers. The average statistical test shown in table 3 supports this result. The average budgetary slack that occurs is higher in the condition of obedience pressure, 73.21 compared to the condition of peer pressure, 46.25 .

Table 4

Hypothesis testing results (Two Ways ANOVA)

\begin{tabular}{|l|c|c|c|c|}
\hline \multicolumn{1}{|c|}{ Source } & df & Mean Square & F & Sig. \\
\hline Corrected Model & 3 & 7446.875 & 3.040 & 0.037 \\
\hline Intercept & 1 & 199804.018 & 81.565 & 0.000 \\
\hline Pressure & 1 & 10179.018 & 4.155 & $0.047^{* *}$ \\
\hline Compensation & 1 & 9911.161 & 4.046 & $0.049^{* *}$ \\
\hline $\begin{array}{l}\text { Pressure*Compensatio } \\
\mathrm{n}\end{array}$ & 1 & 2250.446 & 0.919 & 0.342 \\
\hline Error & 52 & 2449.622 & & \\
\hline Total & 56 & & & \\
\hline Corrected Total & 55 & & & \\
\hline
\end{tabular}

R Square $=0.149$ (Adjusted R Squared $=0.100)$

$* *$ Sig at $5 \%$ level.

The two-way ANOVA test result gives a significance value of 0.049 ( $\mathrm{p}<0.05$ ), which means that hypothesis 2 is supported statistically. Budgetary slack tends to be lower in slack inducing compensation schemes compared to truth inducing compensation schemes. The statistics also provide support for this. Table 3 shows that the average budgetary slack tends to be lower in the slack inducing compensation scheme (46.43) compared to the truth inducing compensation scheme (73.04). 
Table 5

Statistical Mean of Budgetary Slack for Each Manipulation Condition

\begin{tabular}{|c|c|c|c|c|c|}
\hline \multirow{2}{*}{ Pressure } & & \multirow{2}{*}{ Mean } & \multirow{2}{*}{$\begin{array}{l}\text { Std. } \\
\text { Error }\end{array}$} & \multicolumn{2}{|c|}{$\begin{array}{c}\text { 95\% Confidence } \\
\text { Interval }\end{array}$} \\
\hline & & & & $\begin{array}{l}\text { Lower } \\
\text { Bound }\end{array}$ & $\begin{array}{l}\text { Upper } \\
\text { Bound }\end{array}$ \\
\hline \multicolumn{2}{|l|}{ Obedience Pressure } & 73.21 & 9.35 & 54.45 & 91.98 \\
\hline \multicolumn{2}{|l|}{ Peer Pressure } & 46.25 & 9.35 & 27.48 & 65.02 \\
\hline \multicolumn{6}{|l|}{ Compensation } \\
\hline \multicolumn{2}{|l|}{ Slack Inducing } & 46.43 & 9.35 & 27.66 & 65.20 \\
\hline \multicolumn{2}{|l|}{ Truth Inducing } & 73.04 & 9.35 & 54.27 & 91.85 \\
\hline Pressure & Compensation & & & & \\
\hline \multirow{2}{*}{ Obedience Pressure } & Truth Inducing & 92.86 & 13.23 & 66.31 & 119.04 \\
\hline & Slack Inducing & 53.57 & 13.23 & 27.03 & 80.12 \\
\hline \multirow{2}{*}{ Peer Pressure } & Truth Inducing & 53.21 & 13.23 & 26.67 & 79.76 \\
\hline & Slack Inducing & 39.29 & 13.23 & 12.74 & 65.83 \\
\hline
\end{tabular}

Figure 2

Interaction Plot of Pressure and Compensation

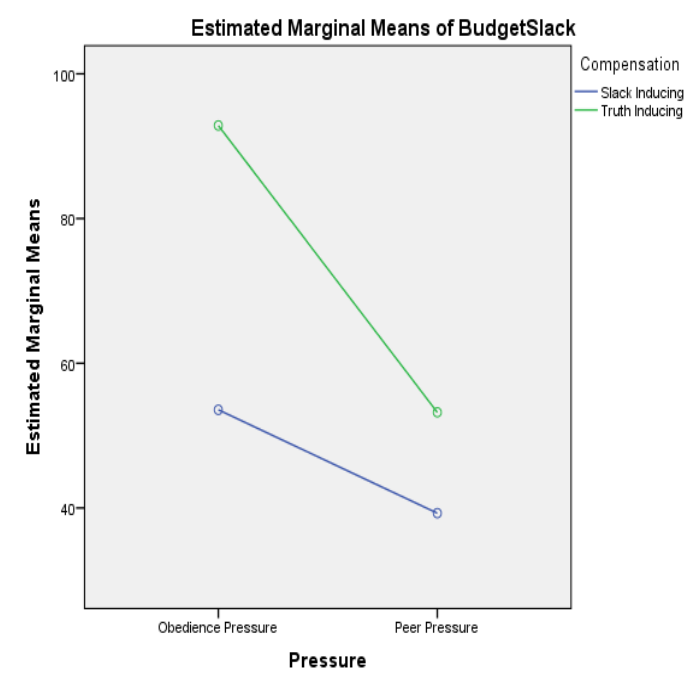

The results of testing hypothesis 3 in table 2 show that the mean difference is not statistically significant, with a significance value of 0.342 ( $p>0.05)$. Based on the hypothesis testing, there is no influence on the interaction between social pressure and compensation schemes on budgetary slack. This is reinforced by the interaction plot in Figure 2, that there is no pattern of interaction formed between social pressure and compensation schemes towards budgetary slack. Based on this, hypothesis 3 is stated to 
be not supported. Therefore, the testing of the simple effects (H3a and H3b) cannot be done because there are no interaction effects of $\mathrm{H} 3$.

\subsection{Discussion}

The tendency of budgetary slack creation is higher when individuals get pressure from superiors than pressure from peers (H1). This result can be explained by social influenced theory (Kelman, 1958), which said that individuals could change their behavior to adjust demand from their social environment, one of which is pressure from superiors and pressure from co-workers-workers.

This research also supported Milgram (1965), which argued that individuals would be willing to behave in ways that deviated from their beliefs and values because they had control from other individuals with higher authority. Deviant behavior due to more authoritative party actions is caused by agency shifts, namely changes in individual psychology from psychological autonomy to agentic conditions. The condition of psychological autonomy is a condition when subordinates have the capacity and ability to determine their own fate and actions (self-determination). While the agentic condition is the condition when the subordinate loses self-determination because there is power from the superior, who asks him to take certain actions (Milgram, 1965), thus when an agentic shift occurs, subordinates will act not on their own desires but because they have to fulfill the desires of figures who are considered to have high authority.

The results of this research supported the research of Davis et al. (2006). Davis et al. (2006) supported this hypothesis, in which most financial managers were proven to do budgetary slack when they were under pressure from superiors, even though they were aware that the action was wrong. Lord and DeZoort (2001) provide similar results. Research Lord and DeZoort (2001) suggest that social pressure raises conformance, namely the desire of individuals to avoid negative consequences due to acts of disloyalty towards someone with higher authority. These results contribute empirically to the literature on social pressure by providing empirical evidence related to research on social pressure originating from superiors and co-workers-workers in their influence on the creation of budgetary slack. 
Hypothesis 2 predicts that budgetary slack tends to be lower in slack inducing compensation schemes than truth inducing. These results can be explained through the theory of expectancy (Vroom, 1994). Expectancy theory (Vroom, 1994) suggests that the willingness of individuals to take certain actions is often influenced by the consequences that will be obtained due to the actions they take. When the expected consequences are more favorable, then the individual's interest in carrying out these actions will be even higher.

Truth inducing compensation scheme (Hobson et al., 2011) is a compensation payment scheme where subordinates will receive maximum compensation when they can achieve results following previously set targets. In the context of the budget, subordinates will receive maximum compensation when they can achieve the budget targets. In line with the theory of expectancy (Vroom, 1994), when faced with maximum compensation, subordinates will try to reach the budget target and make budgetary slack because they feel pressured for the penalty given. Conversely, in the slack inducing compensation mechanism (Hobson et al., 2011), subordinates are paid a fixed salary plus a bonus if they reach the target, but no penalties are given. This condition causes budgetary slack to be lower in slack inducing compensation than the truth inducing compensation scheme because subordinates do not feel pressured about fines given when they do not reach the budget target.

Result of this research reinforces Young's (1985) which suggests that subordinates who face a high risk of uncertainty (penalties in truth inducing schemes), then subordinates avoid these risks (risk-averse) and tend to do budgetary slack compared to subordinates who do not experience uncertainty (incentive scheme slack inducing). Contrary with Waller (1988), Chow et al., (1998), Steven (2002) and Fisher (2002), this research contributes to literature which explains the phenomenon of budgetary slack through the perspective of expectancy theory and provides empirical contributions in order to strengthen Young's (1985).

Hypothesis 3 is not supported, which means that there is no interaction effect of the incentive scheme on the influence of social pressure on the creation of budgetary 
slack. Several reasons can explain these results. First, through a normative social influence perspective (Aronson et al., 2005) that social influence will influence individuals to conform in groups to be accepted by other group members. In the context of social pressure on budgetary slack, the absence of moderation in the incentive sche me can be explained by a normative social influence perspective. Social influence in the form of social pressure tends to be stronger to influence individual behavior so that compensation schemes are less able to mitigate social pressure towards the creation of budgetary slack.

Second, the lack of support for the interaction of incentive schemes against social pressure on budgetary slack can be explained through a framework of moral reasoning and personal value. Hobson et al. (2011) suggest that slack inducing compensation schemes have proven to create a moral framework by placing economic interests on social norms to maintain a sense of honesty and responsibility. However, regardless of the compensation scheme, most participants want a budget that reflects the production they expect. Rankin et al. (2008) and Schatzberg and Stevens (2008) argue that moral judgments of budgetary slack, whether it is ethical or not, depends on the effect of framing felt by each individual.

Financial incentives play a role in determining the moral framework due to perceived pressure on budget planning. However, personal values determine how individuals respond to these moral frameworks and determine what actions will be taken. So, the decision to make budgetary slack under pressure conditions, not only based on financial incentives but on the personal value of each individual. Each individual will respond differently to the financial incentives provided. Therefore, regardless of the type of compensation scheme provided, the moral and personal values of each individual determine their actions regarding budget planning decisions. Morality is the most effective and efficient control for the behavior of self-interest that should not be ignored by economists and accountants (DeGeorge, 1992; Stevens and Theravajan, 2010). 


\section{Conclusion, Implication, and Limitation}

\subsection{Conclusion}

This research aims to examine the effects of compensation schemes and their interactions with social pressure on the creation of budgetary slack. Research results show that budgetary slack tends to be higher when individuals get pressure from superiors than pressure from co-workers-workers. This is because individuals (subordinates) feel the agency shifts. Subordinates will not act on their own desires but because they have to fulfill the desires of figures who are considered to have high authority. This research reinforces the research of Lord and DeZoort (2001) and Davis et al. (2006). Research on social pressure usually only uses one type of social pressure or uses a combination of social pressure, our research made an empirical contribution to the development of social pressure literature by testing two types of social pressures (obedience pressure and peer pressure) and then comparing the value generated.

The budgetary slack tends to be lower in the slack inducing compensation scheme compared to truth inducing. In line with the theory of expectancy (Vroom, 1994), when faced with maximum compensation, the subordinates will try to reach the budget target and make budgetary slack because they feel pressured for fines and penalties given. This condition causes budgetary slack to be lower than the truth inducing compensation scheme because subordinates do not feel pressured about fines given when they do not reach the budget target. Although the results of this research contradict research with Waller (1988), Chow et al., (1998), Steven (2002) and Fisher (2002), this research contributes to literature, namely explaining the phenomenon of budgetary slack through the expectation theory perspective and make empirical contributions in order to strengthen Young's (1985) research. This suggests that subordinates who face a high risk of uncertainty (penalties in truth inducing schemes), then subordinates avoid these risks (risk-averse) and tend to do budgetary slack compared to subordinates who do not experience uncertainty (slack inducing incentive scheme). 
The results indicate the absence of support for the interaction effect of compensation schemes on social pressure tumbling on the creation of budgetary slack. This hypothesis argument does not support for several reasons. In the context of social pressure on budgetary slack, the absence of moderation in the incentive scheme can be explained by a normative social influence perspective namely that social influence in the form of social pressure tends to be stronger to influence individual behavior so that compensation schemes are less able to mitigate social pressure towards the creation of budgetary slack (H3 not supported).

In the context of social pressure on budgetary slack, the absence of moderation in the incentive scheme can be explained by a normative social influence perspective. Social influence in the form of social pressure tends to be stronger to influence individual behavior so that compensation schemes are less able to mitigate social pressure towards the creation of budgetary slack. Financial incentives play an important role in determining the moral framework due to perceived pressure on budget planning. However, personal values determine how individuals respond to these moral frameworks and determine what actions will be taken. So the decision to make budgetary slack under pressure conditions is not only based on financial incentives but also on the moral framework and personal value of each individual.

\subsection{Implication, Limitation, and Suggestions}

This research has theoretical implications that explain the compensation scheme methods to mitigate the phenomenon of budgetary slack through the perspective of expectancy theory (Vroom, 1994). Research provides practical implications that when individuals get stressed, the compensation scheme is less effective in minimizing the effect of social pressure on the creation of budgetary slack. Pressure from supervisor or high-level management become a threat for employee and affects their attitude, although there was not a penalty for their fault. Apart from any compensation, the moral framework and personal values are the most effective and efficient controls for the behavior of self-interest that should not be ignored by economists and accountants. Therefore, the organization should try another control beside monetary compensation 
to create integrity work ambiance, in order to prevent budgetary slack creation in the participative budgeting process.

Our research has several limitations. First, as with experimental research in general, this research has a weakness in external validity. However, the use of other methods such as survey is also quite difficult to do because of the limited number of companies that apply truth inducing compensation scheme. Research related to truth inducing vs. slack inducing compensation schemes has generally only been at the level of theoretical debate. Future research can use other compensation schemes such as clawbacks.

Second, this research only compares two types of social pressure (Obedience Pressure and Peer Pressure). While other pressure, compliance pressure, was not examined in this research. Future research can consider comparing the magnitude of pressure from these three types of pressure. The interesting thing is, in contrast to the two previous types of pressure, some of the studies related to compliance pressure are aimed at reducing the occurrence of budgetary slack.

Third, not all participants respond to social pressures according to the expectations of researchers regarding the treatment given. This is a natural thing in behavioral accounting because various dynamic factors influence the preferences of actors. Future research can be aimed at further research related to what factors cause individuals to be able to resist the pressure given, as well as differences in levels of moral reasoning, religiosity, and gender.

\section{References}

Aronson, E., Wilson, T.D., and Akert, A.M. 2005. Social Psychology (5th ed.). Upper Saddle River, NJ: Prentice-Hall.

Assenso-Okofo, Oheneba, Jahangir Ali, and Kamran Ahmed. 2020. The Effects of Global Financial Crisis on The Relationship between CEO Compensation And Earnings Management. International Journal of Accounting and Information Management. March.

Battiston, P., and S. Gamba. 2016.. International Review of Law and Economics 46 (C): 78-85. 
Bhuyan, R. Butchery, D. Haar, J., and Talukdar, B. 2020, "CEO compensation and firm performance in the insurance industry", Managerial Finance, February.

Brehm, S.S., and S.M, Kassin. 1990. Social Psychology. Boston: Houghton Mifflin Co.

Brunner, Markus \& Ostermaier, Andreas. 2019. Peer Influence on Managerial Honesty: The Role of Transparency and Expectations. Journal of Business Ethics, vol. 154(1), pages 127-145, January.

Cannon, J. N., and T.A. Thornock. 2018. How Do Managers React to A Peer's Situation? The Influence of Environmental Similarity On Budgetary Reporting. Management Accounting Research, 44: 12-25

Carreras, M.G., and Naranjo-Gill, D., 2014. Trust in Superiors and Dysfunctional Behaviors: An Experimental Study on Budgetary Slack. Journal of Positive Management 5 (1): 54-66.

Chen, C.R., Steiner, T.L., and White, A.M. 2001. Risk-Taking Behaviour and Managerial Ownership in The United States Life Insurance Industry. Applied Financial Economics, Vol. 11 No. 2, pp. 165-171.

Chow, C., J. Cooper, and W. Waller. 1988. Participative Budgeting: Effects of a TruthInducing Pay Scheme and Information Asymmetry on Slack and Performance. The Accounting Review 63: 111-122.

Chong, V.K., and Syarifuddin. 2010. Escalation of Commitment to Unprofitable projects: An Experimental Investigation of the Effects of Conformity Pressure and Self-Esteem. Accounting, Accountability, and Performance 6 (1): 1-24.

Davis, Stan, F.T. Dezoort, and L. S. Kopp. 2006. The Effects of Obedience Pressure and Perceived Responsibility on Management Accountants' Creation of Budgetary Slack. Behavioral Research in Accounting 18: 19-36.

DeGeorge, R., 1992. Agency Theory and The Ethics of Agency. In Ethics and Agency Theory: An Introduction, edited by Bowie, N. E., and R. E. Freeman, 59-72. New York, NY: Oxford University Press.

Deutsch, M., and H.B. Gerard. 1955. A Study of Normative and Informational Social Influences Upon Individual Judgement. Journal of Abnormal and Social Psychology 51: 629-636.

Dezoort, F. T., and A. T. Lord. 1997. A Review and Synthesis of Pressure Effects Research in Accounting. Journal of Accounting Literature 16: 28-85.

Douglas, Patricia Casey, and Benson Wier. 2000. Integrating Ethical Dimensions into a Model of Budgetary Slack Creation. Journal of Business Ethics 28 (3): 267-277.

Efrilna, Putri. 2018. Pengaruh Skema Pemberian Insentif dan Tanggung Jawab Personal 
terhadap Budgetary Slack. Jurnal Akuntansi, Vol 6, No. 1.

Emett, Scott A. Ronald N. Guymon, William B. Tayler, Donald Young; 2019. Controls and the Asymmetric Stickiness of Norms. Accounting Horizons, 33 (4): 119-143 (December).

Evans III, J.H. Hannan, L.R. Krishnan and Moser, D.V. 2001. Honesty in Managerial Reporting. The Accounting Review 76 (4): 537-559.

Fahlenbrach, R., and Stulz, R.M., 2011. Bank CEO Incentives and The Credit Crisis. Journal of Financial Economics, Vol. 99 No. 1, pp. 11-26.

Fisher, J.G., L. A. Maines, S.A. Peffer, and G.B. Sprinkle. 2002. Using Budgets for Performance Evaluation: Effects of Resource Allocation and Horizontal Information Asymmetry on Budget Proposals, Budget Slack, and Performance. The Accounting Review 77 (4): 847865 .

Hartman, F. G. H., and V. S. Mass. 2010. Why Business Unit Controllers Create Budget Slack: Involvement in Management, Social Pressure, and Machiavellianism. Behavioral Research in Accounting 22 (2): 27-49.

Hobson, J. L., M. J. Mellon, and D. E. Stevens. 2011. Determinants of Moral Judgements Regarding Budgetary slack: An Experimental Examination of Pay Scheme and Personal Values. Behaviorial Research in Accounting 23 (1): 87-107.

Huddart, S., Qu, H., 2014. Rotten Apples and Sterling Examples: Moral Reasoning and Peer Influences On Honesty In Managerial Reporting (Working Paper). Pennsylvania State University.

Kelman, H. C., 1958. Compliance, Identification, and Internalization Three Processes of Attitude Change. Journal of Conflict Resolution 2(1): 51-60.

Khera, I. P., and J.D. Benson. 1970. Are Students Really Poor Substitutes for Businessman in Behavioral Research. Journal of Marketing Research 7: 529-532.

Kramer, S., and F. Hartman. 2014. How top-down and Bottom-up Budgeting Affect Budget Slack and Performance Trough Social and Economic Exchange. ABACUS 50 (3): 314340 .

Langevin, P., and Mendoza, C., 2012. How Can Management Control System Fairness Reduce Managers'unethical Behaviours?, European Management Journal, Vol. 31 No. 3, pp. 209-222.

Lord, A.T., and F. T. DeZoort. 2001. The Impact of Commitment and Moral Reasoning on Auditor's Responses to Social Influence Pressure. Accounting, Organization, and Society 25: 215-235. 
Milgram, S., 1965. Some Conditions of Obedience and Disobedience to Authority. Human Relations 18: 57-76.

.1974. Obedience to Authority: An Experimental View. New York: Harper and Row. Nahartyo, E., and I. Utami. 2016. Panduan Praktis Riset Eksperimen. Jakarta: Index

Palupi, Monika and Mulyatno, C.B. Interaction Effects Of Reward Scheme and Identity on Budgetary Slack: The Perspective Of Morality. Southeast Asia Journal of Contemporary Business, Economics, and Law, 2014. Vol. 5, Issue 1 (Dec.)

Pepper, A., and Gore, J. 2015. Behavioral Agency Theory: New Foundations for Theorizing about Executive Compensation. Journal of Management, Vol. 41 No. 4, pp. 1045-1068.

Rankin, F., S. Schwartz., and R. Young. 2008. The Effects of Honesty and Superior Authority on Budget Proposals. The Accounting Review 83 (4): 1083-1099.

Sampouw, Chrishella Erlyn. 2018. Experimental Study: The Influence of Pay Scheme and Personal Value to Budgetary Slack. Jurnal Aplikasi Manajemen, Vol 16, No 4.

Schatzberg, J., and D. Stevens. 2008. Public and Private Forms of Opportunism Within the Organization: A Joint Examination of Budget and Effort Behavior. Journal of Management Accounting Research 20: 59-81.

Steven, D.E., 2002. The Effects of Reputation and Ethics on Budgetary Slack. Journal of Management Accounting Research 14: 153-171. and A. Thevaranjan. 2010. A Moral Solution to the Moral Hazard Problem. Accounting, Organizations, and Society 35 (1): 125-139.

Turner, J.C., Hogg, M.A., Oakes, P.J., Reicher, S.D., and Wetherell, M.S. 1987. Rediscovering the social group: A self-categorization theory. Oxford and New York: Basil Blackwell.

Van Essen, M., Otten, J. and Carberry, E.J. 2015. Assessing managerial power theory: a metaanalytic approach to understanding the determinants of CEO compensation. Journal of Management, Vol. 41 No. 1, pp. 164-202.

Vroom, V. H., 1994. Work and Motivation. New York: John Wiley \& Sons

Waller, W.S., 1988. Slack in Participative Budgeting: The Joint Effect of a Truth Inducing Pay Scheme and Risk Preferences. Accounting, Organizations, and Society 13: 87-98.

Webb, R. A., 2002. The Impact of Reputation and Variance Investigations on the Creation of Budget Slack. Accounting, Organizations, and Society 27 (4): 361-378.

Young, S. M., 1985. Participative budgeting: The Effects of Risk Aversion and Asymmetric Information on Budgetary Slack. Journal of Accounting Research 23 (2): 829-842. 


\section{APPENDIX}

\section{Experimental Instrument}

WELCOME TO

PT. PRIMA JAYA OTOPARTS, Tbk.

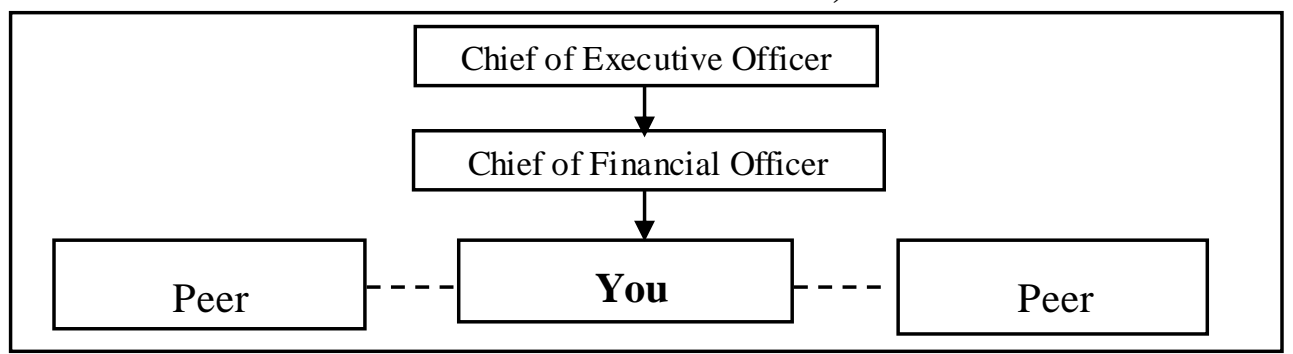

PT. Prima Jaya Otoparts, Tbk. is one of the national companies engaged in machinery and automobile parts. You have joined the company for two years and served as a MANAGEMENT ACCOUNTANT who is responsible for helping financial managers in strategic and operational decision making, including the preparation of budget proposals. You are also responsible for the results of decisions taken, including in determining the amount of profit targets at the beginning of each budgeting period. At this time, you and the company's finance department are preparing a proposal plan for the 2019 budget target.

\section{TRUTH INDUCING}

Realization of the budget for the last 3 years:

\begin{tabular}{|c|c|c|c|c|}
\hline Year & Profit Target & $\begin{array}{c}\text { Realized } \\
\text { profit }\end{array}$ & Result & Compensation obtained \\
\hline $\mathbf{2 0 1 6}$ & 13,1 Billion & 13,5 Billion & $\begin{array}{c}\text { Target } \\
\text { Achieved }\end{array}$ & $\begin{array}{c}\text { Salary }+50 \% \text { bonus } \\
\text { from the salary amount for 3 months }\end{array}$ \\
\hline $\mathbf{2 0 1 7}$ & 14,9 Billion & 14,5 Billion & $\begin{array}{c}\text { Target Not } \\
\text { reached }\end{array}$ & $\begin{array}{c}\text { No bonus + get a salary reduction } \\
\text { penalty of } 10 \% \text { for 3 months }\end{array}$ \\
\hline $\mathbf{2 0 1 8}$ & 14,2 Billion & 14,9 Billion & $\begin{array}{c}\text { Target } \\
\text { Achieved }\end{array}$ & $\begin{array}{c}\text { Salary }+50 \% \text { bonus } \\
\text { from the salary amount for } 3 \text { months }\end{array}$ \\
\hline $\mathbf{2 0 1 9}$ & \multicolumn{3}{|c|}{ Still in the process of budgeting } \\
\hline
\end{tabular}


The Compensation Scheme that applies to the company is:

A. If the company succeeds in achieving the profit target, then each employee will obtain a $50 \%$ bonus from the salary amount.

Example: Your salary is IDR 10,000,000. Besides getting a salary, you will also get a bonus of 5,000,000 IDR from the company. So, the total income you earn is $\mathbf{1 5 , 0 0 0 , 0 0 0 ~ I D R . ~}$

B. If the profit tag is not reached, then the employee salary will be deducted by $10 \%$ for 3 months as a penalty (fine) because it does not succeed in achieving the budget target.

Example: Your salary is 10,000,000 IDR. Besides not getting a bonus, you will also get a deduction (fine) of IDR 1,000,000 IDR from the company. So, the total income that you earn is $\mathbf{9 , 0 0 0 , 0 0 0 ~ I D R . ~}$

\section{SLACK INDUCING}

Realization of the budget for the last 3 years:

\begin{tabular}{|c|c|c|c|c|}
\hline Year & $\begin{array}{l}\text { Profit } \\
\text { Target }\end{array}$ & $\begin{array}{c}\text { Realized } \\
\text { profit }\end{array}$ & Result & Compensation obtained \\
\hline 2016 & 13,1 Billion & 13,5 Billion & $\begin{array}{c}\text { Target } \\
\text { Achieved }\end{array}$ & $\begin{array}{l}\text { Salary }+50 \% \text { bonus } \\
\text { from the salary amount for } 3 \\
\text { months }\end{array}$ \\
\hline 2017 & 14,9 Billion & 14,5 Billion & $\begin{array}{c}\text { Target Not } \\
\text { reached }\end{array}$ & Salary + Without Bonus \\
\hline 2018 & 14,2 Billion & 14,9 Billion & $\begin{array}{c}\text { Target } \\
\text { Achieved }\end{array}$ & $\begin{array}{c}\text { Salary }+50 \% \text { bonus } \\
\text { from the salary amount for } 3 \\
\text { months }\end{array}$ \\
\hline 2019 & \multicolumn{4}{|c|}{ Still in the process of budgeting } \\
\hline
\end{tabular}

The Compensation Scheme that applies to the company is:

A. If the company succeeds in achieving the profit target, then each employee will obtain a $50 \%$ bonus from the salary amount.

Example: Your salary is 10,000,000 IDR. Besides getting a salary, you will also get a bonus of 5,000,000 IDR from the company. So, the total income that you earn is $\mathbf{1 5 , 0 0 0 , 0 0 0 ~ I D R . ~}$ 
B. If the profit is not reached, the employee only will get a salary without a bonus from the company.

Example: Your salary is $10,000,000 \mathrm{IDR}$. So, you will only get a basic salary of Rp. 10,000,000 IDR, without any bonus.

\section{TASK.}

1. Your monthly salary is $12,000.000$ IDR. If the budget target is successfully achieved, calculate how much total income per month that you will receive?

.IDR

2. Your monthly salary is $12,000.000 \mathrm{IDR}$. If the budget target is not achieved, calculate how much total income per month that you will receive?

IDR

\section{PRESENT CONDITION}

The best estimation analysis conducted by the company's research team showed that the company's profit performance could reach 15,500,000,000 IDR (Billion) in 2019. The company's code of ethics requires every employee to be honest by entering the appropriate budget actual estimation.

\section{OBEDIENCE PRESSURE}

One day before the budget proposal is submitted, Mr. GUNAWAN, the financial manager who is your direct supervisor, (without the knowledge of the managing director) gives the order and forces you to make a budget proposal with a profit target that is smaller than the estimate, to only 14,000. 000,000 IDR (billion). This is done so that the company's target becomes easier to achieve so that all employees have the opportunity to get company bonuses. Mr. Gunawan threatened to give a poor performance evaluation and could even fire you from work if you did not follow his orders. However, you realize that this action is an act of cheating and harming the company. 


\section{PEER PRESSURE}

One day before the budget proposal is submitted, your accountant's peers, Mr. RIZAL \& Mr. ANTON (without the knowledge of the financial manager and president director) urges you to make a budget proposal with a profit target that is smaller than the existing estimate, to only $\mathbf{1 4 , 0 0 0 , 0 0 0 , 0 0 0}$ IDR (Billion). This is done so that the company's target becomes easier to achieve so that all employees have the opportunity to get company bonuses. However, you realize that this action is an act of cheating and harming the company.

\section{BUDGET DECISION}

How much the profit budget that you will submit to top management?

IDR 